\title{
IDENTIFIKASI RESPON PERTUMBUHAN GENOTIPE Moringa Oleifera (L) DALAM MENINGKATKAN KOMPONEN HASILPRODUKSI
}

\author{
Isdiantoni $^{1)}$, Henny Diana Wati, ${ }^{2)}$ \\ ${ }^{1}$ FakultasPertanian, Universitas Wiraraja,antonie_isd@yahoo.co.id \\ ${ }^{2}$ Fakultas Pertanian, Universitas Wiraraja, hennydianawati@yahoo.co.id
}

\begin{abstract}
ABSTRAK
Tanaman kelor (Moringa Oleifera $(\mathrm{L})$ tumbuh baik di pekarangan tanpa adanya teknik budidaya. Saat ini penelitian tentang MoringaOleifera $(\mathrm{L})$ lebih banyak di bidang farmakologinya saja, oleh karena itu perlu adanya penelitian di bidang teknik budidaya yang tepat. Teknik budidaya dengan pemangkasan yang tepat diharapkan mampu menghasilkan produksi yang lebih baik. Penelitian ini mencoba mengidentifikasi pengaruh pemangkasan terhadap respon pertumbuhan tanaman kelor (Moringa Oleifera $(\mathrm{L})$ ) dalam meningkatkan komponen hasil produksi lebih baik atau tidak jika diberikan perlakuan pemangkasan.Hasil pengamatan pada umur 90 HST terlihat bahwa semua parameter yang diujikan terhadap komponen pertumbuhan dan produksi biomas genotipe Moringa Oleifera (L) berpengaruh sangat nyata terhadap perlakuan pemangkasan. Perlakuan teknik pemangkasan dengan ketinggian $120 \mathrm{~cm}$ dari atas permukaan tanah menghasilkan pertumbuhan dan produksi tanaman Moringa oleifera (L) tertinggi. Berdasarkan data hasil pengamatan respon pertumbuhan genotipe Moringa Oleifera (L) dalam meningkatkan komponen hasil produksi mengindikasikan bahwa dengan perlakuan pemangkasan $120 \mathrm{~cm}$ dari permukaan tanah yang berpengaruh sangat nyata. Oleh karena itu untuk teknik pemangkasan tanaman Moringa Oleifera (L) perlakuan pemangkasan $120 \mathrm{~cm}$ yang dapat meningkatkan komponen hasil produksi.
\end{abstract}

Kata kunci : Moringa Oleifera (L), Teknik Pemangkasan, Produksi

\section{PENDAHULUAN}

Indonesia dikenal berpotensi

dalam keanekaragaman hayati yang telah dimanfaatkan sejak dulu. Tanaman kelor (Moringa oleifera, Lamk) adalalah salah satu tanaman mudah dibudidayakan di Indonesia dan bermanfaat.

\footnotetext{
Alamat Koresponden:

Isdiantoni $^{1 \text { ), }}$

Fakultas Pertanian, Universitas

Wiraraja, Jl. Raya Sumenep-

Pamekasan Km. 5 Patian-Sumenep

Email: antonie_isd@yahoo.co.id

Henny Diana Wati, ${ }^{2}$

${ }^{2}$ Fakultas Pertanian, Universitas

Wiraraja,

hennydianawati@yahoo.co.id. Jl.

Raya Sumenep-Pamekasan Km. 5

Patian-Sumenep. Email:

hennydianawati@yahoo.co.id
} 
Pemeliharaan tanaman kelor (Moringa oleifera $(\mathrm{L})$ ) sangat minimal, cepat tumbuh, berbunga dan berbuah. Perbanyakan tanaman kelor dapat menggunakan stek maupun biji. Tanaman ini dalam umur 3 tahun akan menghasilkan 400-600 polong/tahun, sedangkan untuk pohon dewasa menghasilkan 1600 polong/tahun. Musim, tinggi dan interval pemotongan berpengaruh terhadap produksi biomas tanaman kelor.

Daun dan buah kelor mempunyai nilai ekonomis karena beberapa petani menjualnya ke pasar. Hanya saja, budidaya tanaman kelor belum banyak dipelajari dan dikembangkan untuk mengoptimalkan hasil produksi daun berkualitas tinggi.

Pemangkasan merupakan salah satu cara untuk mengurangi dominasi apikal (tunas ujung) yang bertujuan untuk merangsang pertumbuhan tunas-tunas samping atau tunas lateral sehingga pertumbuhan tanaman menjadi lebih ideal dan seimbang. Daun yang berada di bagian terdalam tidak akan mengalami proses fotosintesis akibat tidak terkena sinar matahari langsung. Daun ini akan bersifat parasit bagi tanaman menggunakan fotosintesa yang terbentuk dari daun yang terkena sinar matahari langsung untuk partumbuhan tanaman.

Pertumbuhan tanaman yang lebih optimal akan memberikan hasil yang optimal juga. Lingkungan mikro yang baik akan memberikan dampak yang baik bagi pertumbuhan tanaman tersebut. Hal tersebut juga didukung oleh pengurangan kelembaban berlebihan, perkembangan jamur dan organisme pengganggu tanaman (OPT) lainnya.

Daun kelor memiliki banyak manfaat untuk kesehatan tubuh, karena kaya akan kandungan nutrisi dan senyawa yang di butuhkan tubuh. Daun kelor memiliki kandungan 46 (empat puluh enam) antioksidan kuat, yaitu senyawa yang melindungi tubuh terhadap efek kerusakan dari radikal bebas dengan menetralkannya sebelum dapat menyebabkan kerusakan sel dan penyakit. Sementara itu Fuglie LJ dalam The Miracle Tree : The Multiple Attribute of Moringa, sebagaimana dikutip dari Krisnadi (2012), menyebutkan daun kelor 
segar (cat.: dalam proporsi berat yang sama) mengandung antara lain:

(a) vitamin $\mathrm{C}$, dengan kandungan kurang lebih 7 (tujuh) kali lebih banyak dibandingkan dengan jeruk,

(b) vitamin A, dengan kandungan kurang lebih 4 (empat) kali lebih banyak dibandingkan dengan wortel,

(c) kalsium, dengan kandungan kurang lebih 4 (empat) kali lebih banyak dibandingkan dengan susu (tanpalaktosa),

(d) kalium, dengan kandungan kurang lebih 3 (tiga) kali lebih banyak disbandingkan dengan pisang,

(e) protein, dengan kandungan kurang lebih 2 (dua) kali lebih banyak dibandingkan dengan yoghurt, serta

(f) zat besi, dengan kandungan kurang lebih 25 (duapuluh lima) kali lebih banyak dibandingkan dengan bayam.

Orang Madura mendapatkan tanaman kelor (Moringa oleifera (L)) bukan melalui tanaman budidaya, namun dari pengambilan langsung di pekarangan rumah. Tanaman kelor (Moringa oleifera (L)) tumbuh baik di pekarangan tanpa adanya teknik budidaya. Saat ini penelitian tentang Moringa Oleifera (L) lebih banyak di bidang farmakologinya saja, oleh karena itu perlu adanya penelitian di bidang teknik budidaya yang tepat.

Teknik budidaya dengan pemangkasan yang tepat diharapkan mampu menghasilkan produksi yang lebih baik.Penelitian ini mencoba mengidentifikasi pengaruh pemangkasan terhadap respon pertumbuhan tanaman kelor (Moringa oleifera (L)) dalam meningkatkan produksi komponen hasil lebih baik atau tidak jika diberikan perlakuan pemangkasan.

Penelitian ini bertujuan untuk mengidentifikasipengaruh pemangkasan terhadap respon pertumbuhan tanaman kelor (Moringa oleifera) dalam meningkatkan produksi komponen hasil. Manfaat dari penelitian ini diperoleh informasi adanya pengaruh pemangkasan genotipe Moringa Oleifera (L)yang tepat dengan menghasilkan pertumbuhan dan hasil produksi yang maksimal. 


\section{METODE PENELITIAN}

\section{Jenis Penelitian}

Penelitian ini merupakan penelitian percobaan yang dilakukan di Desa Poteran Kec. Talango Kab. Sumenep

\section{Rancangan Penelitian}

Rancangan Percobaan dalam penelitian ini adalah dengan menggunakan Rancangan Acak Kelompok(RAK)yang terdiri 3 (tiga) perlakuan dengan 5 ulangan. Dengan perlakuan pemangkasan $50 \mathrm{~cm}$ dari permukaan tanah (P1), Pemangkasan $120 \mathrm{~cm}$ dari permukaan tanah (P2), dan Pemangkasan $150 \mathrm{~cm}$ dari permukaan tanah (P3)

\section{Lokasi Penelitian}

Penelitian dilaksanakan di DesaTalangopada ketinggian $<500$ diatas permukaan laut dengan jenis tanahmediteranlitosol (coklat)

\section{Tahapan Penelitian}

Genotipe Moringa Oleifera (L) yang akan dijadikan penelitian dipilih yang sehat dan seragam terutama untuk diameter batang.dan tinggi tanaman. Semua genotipe Moringa Oleifera (L) rata-rata sudah berumur satu tahun.

Penanaman di lahan dilakukan dengan jarak tanam $1 \mathrm{mx} 1 \mathrm{~m}$.
Penyiraman/pengairan diberikan setiap hari sampai umur 90 HST. Perlakuan pemangkasan dilakukan pada saat tanaman berumur 30 HST. Pemanenan dilakukan pada umur 60 hari setelah pemangkasan (HSP) semua tanaman langsung dipanen.

Pengamatan komponen pertumbuhan meliputi Tinggi Tanaman, Diameter Batang dan Jumlah Ranting. Pengamatan komponen produksi meliputi bobot segar daun, dan Berat Total Tanaman.

\section{Analisis Data}

Penelitian dilaksanakan dengan menggunakan Rancangan Acak Kelompok dengan dua genotipe Moringa Oleifera (L) dan lima ulangan. Menurut Gazpersz (1994), model linier untuk Rancangan Acak Kelompok adalah :

$$
\begin{aligned}
\text { Yij } & =\boldsymbol{\mu}+\sigma \mathbf{i}+\boldsymbol{\beta} \mathbf{j}+\mathbf{\varepsilon i j} \\
\mathrm{i} & =1,2,3 \\
\mathrm{j} & =1,2,3,4,5
\end{aligned}
$$

dalam hal ini :

$$
\begin{aligned}
& \text { Yij = nilai pengamatan dari } \\
& \text { perlakuan ke-i dalam kelompok } \\
& \text { ke- } \mathbf{j} \\
& \boldsymbol{\mu}=\text { nilai tengah populasi } \\
& \boldsymbol{\sigma} \mathbf{i}=\text { pengaruh aditif dari genotipe }
\end{aligned}
$$


ke-i

$\beta \mathbf{j}=$ pengaruh aditif dari ulangan ke-j

$\boldsymbol{\varepsilon} \mathbf{i j}=$ pengaruh galat percobaan dari perlakuan ke-i pada ulangan ke-j

Data dari hasil pengamatan pertumbuhan dan produksi diolah berdasarkan analisis varian (Anova). Apabila data hasil analisis berbeda nyata maka dilanjutkan dengan uji pembedaan dengan menggunakan uji Duncan 5\%.

\section{HASIL YANG DICAPAI}

\section{A. Pertumbuhan}

Tanaman

\section{Moringa Oleifera (L)}

Pemangkasan

tanaman

dilakukan untuk mengendalikan pertumbuhan dan memperbaiki kualitas produksi tanaman Moringa Oleifera (L). Dengan demikian perlakuan pemangkasan diharapkan arsitektur daun Moringa Oleifera (L) akan menjadi kompak, agar proses fotosintesis lebih efektif dan translokasi unsur hara bisa makin cepat.

Bagian pucuk tanaman merupakan jaringan meristem apikal yang merupakan sumber pembentukan dari auksin, padabagian ini pula aktivitas pembelahan sel tinggi sekali.
Tinggi tanaman akan dibatasi dengan perlakuan pemangkasan yaitu dengan cara melakukan pemotongan batang tanaman Moringa Oleifera (L), yang disesuaikan dengan perlakuan yang diberikan $(50 \mathrm{~cm}$, $120 \mathrm{~cm}$ dan $160 \mathrm{~cm}$ ) dari permukaan tanah. Tanaman yang dipangkas merupakan tanaman Moringa Oleifera (L) yang sehat, tidak sakit karena hama dan penyakit, tidak ada luka dan patah.

Perlakuan pemangkasan berpengaruh terhadap semua parameter yang diamati dalam percobaan ini. Berdasarkan hasil uji statistik terlihat bahwa semua parameter komponen pertumbuhan yang diamati berbeda nyata antar perlakuan yang diuji Tabel 1).

Tabel 1. Nilai Uji F dari parameter komponen pertumbuhan dengan perlakuan pemangkasan.

\begin{tabular}{|c|c|c|c|}
\hline No. & Perlakuan & $\mathrm{db}$ & Nilai $F$ \\
\hline 1. & $\begin{array}{l}\text { Tinggi } \\
\text { Tanaman }\end{array}$ & 2 & $199,214^{* *}$ \\
\hline 2. & $\begin{array}{l}\text { Diameter } \\
\text { Batang }\end{array}$ & 2 & $240,012^{* *}$ \\
\hline 3. & Jumlah Cabang & 2 & $25,200^{* *}$ \\
\hline 4. & Jumlah Ranting & 2 & $153,815^{\text {** }}$ \\
\hline
\end{tabular}

Keterangan :

$*$ = nyata $\quad * *=$ sangat nyata 
Pada tabel 1 menunjukkan hasil anova nilai $\mathrm{F}$ dengan Sig. = $0,000(<0,05)$ yang berarti rata-rata parameter komponen pertumbuhan tanaman Moringa Oleifera (L) untuk masing - masing perlakuan pemangkasan berbeda secara nyata. Hal ini menandakan pemangkasan dapat merangsang translokasi hormon tumbuh yang berupa auksin, pada bagian sekitar daerah pemangkasan sehingga akan merangsang pembentukan cabang baru.

Menurut Dwijoseputro (1983), pemangkasan tanaman bagian atas akan menyebabkan menghilangnya dominansi apikal dan mendorong pertumbuhan tunas baru pada bagian aksiler batang utama. Dominansi apikal yang dimaksud adalah pengaturan pertumbuhan dominansi pada tanaman yang bertujuan untuk menekan daerah meristematik (Hastuti et.al., 2000).
Tabel 2. Pengaruh pemangkasan terhadap parameter komponen pertumbuhan

\begin{tabular}{|c|c|c|c|c|c|}
\hline $\mathrm{N}$ & $\begin{array}{c}\text { Perl } \\
\text { ak }\end{array}$ & $\begin{array}{l}\text { Tin } \\
\text { gg } \\
\text { Tan }\end{array}$ & $\begin{array}{c}\text { Diam } \\
\text { eter }\end{array}$ & $\begin{array}{c}\mathrm{Jm} \\
\mathrm{lh} \\
\mathrm{Ca} \\
\mathrm{b}\end{array}$ & $\begin{array}{c}\text { Jmlh } \\
\text { Rant } \\
\text { ing }\end{array}$ \\
\hline 1. & $\mathrm{P} 1$ & $\begin{array}{l}308 \\
4^{\mathrm{a}}\end{array}$ & $6,36^{\mathrm{a}}$ & $\begin{array}{c}3,6 \\
\mathrm{~b}\end{array}$ & $44,6^{\mathrm{a}}$ \\
\hline 2. & $\mathrm{P} 2$ & $\begin{array}{l}338 \\
4^{\mathrm{b}}\end{array}$ & $9,56^{\mathrm{c}}$ & $\begin{array}{c}4,8 \\
\mathrm{c}\end{array}$ & $84,8^{\mathrm{c}}$ \\
\hline 3. & P3 & $\begin{array}{l}383 \\
6^{c} \\
\end{array}$ & $8,58^{\mathrm{b}}$ & $\begin{array}{c}3,0 \\
\mathrm{a}\end{array}$ & $69,0^{b}$ \\
\hline
\end{tabular}

Dari hasil uji lanjut Duncan menunjukkan tanaman Moringa Oleifera (L) bahwa rata-rata perlakuan P2 dengan pemangkasan $120 \mathrm{~cm}$ dari permukaan tanah mempunyai pengaruh yang sangat signifikan terhadap komponen pertumbuhan tanaman.

Pemangkasan pada tanaman dapat mempengaruhi pertumbuhan dan produksi pada bagian aksiler batang. Pemangkasan adalah suatu kegiatan mengurangi organ tertentu pada bagian tumbuh tanaman yang tujuannnya untuk meningkatkan dan mengoptimalisasi pertumbuhan dan produksi tanaman.

Pemangkasan menurut Ferdinandus, (2014) yaitu dengan pengurangan organ tumbuh tanaman sehingga hanya tersisa tajuk tanaman, tujuannya adalah optimasi penerimaan intersepsi cahaya dan 
ketersediaan $\mathrm{CO}_{2}$ oleh tanaman. Adanya pengaruh suhu yang lebih rendah dalam tajuk dapat mempengaruhi pembentukan jumlah cabang tanaman.

Sama hal nya dengan hasil anova jumlah ranting tanaman Moringa Oleifera (L) menggunakan uji $\mathrm{F}$ (Tabel 1) menunjukkan nilai $\mathrm{F}$ $=153,815$ dengan Sig. $=0,000$ $(<0,05)$ yang berarti rata-rata Jumlah ranting tanaman Moringa Oleifera (L) untuk masing-masing pemangkasan berbeda secara nyata. Kemudian di uji lanjut Duncan maka diperoleh pemangkasan $120 \mathrm{~cm}$ dari permukaan tanah yang memiliki Jumlah ranting tertinggi (Tabel 2).

Pada penelitian ini, hasil dari perlakukan tinggi pemangkasan berpengaruh sangat nyata terhadap semua parameter pertumbuhan. Hal ini berarti tanaman Moringa Oleifera (L) yang di pangkas dengan perlakuan tinggi pemangkasan yang berbeda akan memproduksi pertumbuhan yang berbeda pula. Selanjutnya berdasarkan uji lanjut dengan menggunakan duncan diketahui bahwa produksi pertumbuhan terbanyak terdapat pada tanaman Moringa Oleifera (L) yang dipangkas dengan perlakuan pemangkasan $120 \mathrm{~cm}$.

Bertambah tingginya pemangkasan $\quad(>120 \mathrm{~cm} \quad$ dari permukaan tanah) menyebabkan adanya penurunan produksi pertumbuhan yang dihasilkan tanaman Moringa Oleifera (L). Dachlan, dkk (2006) mengatakan bahwa adanya ketersediaan faktorfaktor pendukung pertumbuhan seperti, cahaya dan $\mathrm{CO}_{2}$, akan meningkatkan laju respirasi dan jumlah fotosintat yang diperlukan dalam pembentukan cabang simpodia / generatif.

Untuk pembentukan cabang tanaman diperlukan senyawasenyawa tertentu sebagai perangsang pembentukan cabang antara lain auksin, sukrosa dan senyawa nitrogen. Senyawa-senyawa tersebut disintesa dalam daun kemudian ditranslokasikan ke bagian yang dipangkas. Akumulasi dari senyawasenyawa tersebut akan merangsang pembentukan cabang baru.

\section{B. Pemangkasan Terhadap Produksi Tanaman Moringa Oleifera $(\mathbf{L})$}

Pemangkasan produksi merupakan pemangkasan untuk 
merangsang tumbuhnya tunas yang produktif, yaitu tunas yang berada di bagian tajuk terluar tanaman. Berdasarkan hasil pengamatan selama 90 HST berat daun segar tanaman Moringa Oleifera rata-rata adalah $0,65 \mathrm{~kg}$.

Tabel 3. Nilai uji $\mathrm{F}$ dari parameter komponen hasil produksi

\begin{tabular}{clcc}
\hline No. & Perlakuan & $\mathrm{db}$ & Nilai F \\
\hline 1. & Berat Segar & 2 & $112,625^{* *}$ \\
Daun & $\begin{array}{l}\text { Berat Total } \\
\text { 2. }\end{array}$ & 2 & $113,669^{* *}$ \\
\hline
\end{tabular}

Keterangan :

$*$ = nyata $\quad * *=$ sangat nyata

Berdasarkan tabel 3 semua parameter menunjukkan hasil signifikan terhadap komponen hasil produksi.. Berat segar daun menunjukan nilai uji $\mathrm{F}=112,625$ dengan Sig. $=0,000(<0,05)$ yang berarti rata-rata berat segar daun Moringa Oleifera (L) untuk masingmasing perlakuan pemangkasan berbeda secara nyata. Proses fotosintesis pada daun berjalan baik sehingga pertumbuhan tanaman juga akan meningkat. Sejalan dengan pernyatan Gardner (1991), menyatakan bahwa fungsi utama daun dalam proses fotosintesis yaitu menghasilkan asimilat yang bermanfaat untuk pertumbuhan dan produksi tanaman.

Begitu pula pada berat total tanaman Moringa Oleifera (L) menggunakan uji $\mathrm{F}$ menunjukkan nilai $\mathrm{F}=1131,669$ dengan Sig. = $0,000(<0,05)$ yang berarti rata-rata berat total tanaman Moringa Oleifera (L) untuk masing-masing pemangkasan berbeda secara nyata.

Tabel 4. Pengaruh Pemangkasan terhadap komponen hasil produksi hasil uji lanjut Duncan

\begin{tabular}{cccc}
\hline No. & Perlak & $\begin{array}{c}\text { Berat } \\
\text { Segar } \\
\text { Daun }\end{array}$ & $\begin{array}{c}\text { Berat } \\
\text { Total } \\
\text { Tanaman }\end{array}$ \\
\hline 1. & P1 & $0,3440^{\mathrm{a}}$ & $2,3220^{\mathrm{a}}$ \\
2. & P2 & $0,6520^{\mathrm{c}}$ & $5,2600^{\mathrm{c}}$ \\
3. & P3 & $0,4820^{\mathrm{b}}$ & $4,6920^{\mathrm{b}}$ \\
\hline
\end{tabular}

Dari hasil uji lanjut Duncan menunjukkan bahwa rata-rata berat segar daun Moringa Oleifera (L) menunjukkan bahwa rata-rata berat segar daun tanaman oleh perlakukan P2 dengan pemangkasan $120 \mathrm{~cm}$ dari permukaan tanah yang memiliki berat segar daun tertinggi sebesar 0,652 kg (Tabel 4). Smith dan Jones (1984) dalam Dachlan, dkk., (2006) menyatakan bahwa laju pertukaran karbondioksida per unit luas daun tanaman berbanding lurus dengan 
jumlah intersepsi dan penerimaan cahaya pada tanaman.

Sedangkan uji lanjut Duncan perlakuan P2 pemangkasan $120 \mathrm{~cm}$ dari permukaan tanah yang memiliki berat total tanaman tertinggi sebesar $5,2600 \mathrm{~kg}$ (Tabel 4).

Pertumbuhan dan perkembangan organ-organ vegetatif tanaman akan dipengaruhi oleh intensitas cahaya yang diterima oleh tanaman tersebut. Meningkatnya pertumbuhan dan perkembangan tanaman akan diikuti dengan meningkatnya akumulasi bahan kering pada tanaman. Pada awal pertumbuhan tanaman partisi bahan kering menuju daun akan mengalami peningkatan. Setelah tanaman mencapai fase generatif partisi bahan kering ke daun lambat laun mengalami penurunan. Pada fase generatif akan terjadi proses penuan dari daun, akar daun dan batang. Semua proses akan berjalan dengan sempurna jika ketersediaan cahaya yang cukup untuk kelangsungan proses fotosintersis.

\section{KESIMPULAN DAN SARAN}

\section{A. Kesimpulan}

1. Perlakuan pemangkasan terhadap respon pertumbuhan tanaman kelor (Moringa oleifera) dalam meningkatkan produksi komponen hasil berpengaruh nyata terhadap semua parameter yang diamati dalam percobaan ini.

2. Perlakuan P2 yaitu tinggi pemangkasan $120 \mathrm{~cm}$ dari atas permukaan tanah menghasilkan pertumbuhan dan produksi tanaman Moringa oleifera (L) tertinggi.

\section{B. Saran}

Diperlukan penelitian lebih lanjut mengenai uji tingkat keberhasilan stek dari tunas dan perlakuan waktu pemangkasan untuk mengetahui efektifitas teknik pemangkasan pada tanaman Moringa Oleifera (L). 


\section{DAFTAR PUSTAKA}

Ahmad, D.H. dan Hamzah. 1993. Vegetative Propagation of Tropical Tree Species by Stem Cutting. Report Number 21. Multipurpose Tree Research Network. Project Winrock International The USA International Agency for International Dev.

Aminah, H. 2001. Vegetative Propagation of Endospemum malacense by Leavy Stem Cutting: Effect of IBA Concentration and Propagation System (mist and non mist). Journal of Tropical Forest ScienceVol 15 (2): 249 258.

Dachlan, A., D. Dan S. Kamaruddin. 2006. Pengaruh Pemangkasan terhadap pertumbuhan dan produksi tanaman kapas transgenic. Jurnal Agrovigor 5 (2):182-189.

Dwidjoseputro, D. 1994. Pengantar Fisiologi Tumbuhan. Gramedia Pustaka Utama, Jakarta.

Ferdinandus DM, Panggabean. Lisa Mawarni. T. Chairun Nissa. 2014. Respon Pertumbuhan dan Produksi Bengkuang (Pachyrhizus erosus (L) Urban) terhadap waktu Pemangkasan dan Jarak Tanam. Jurnal Agroekoteknologi. 5 (2):702711

Gasperz, V. 1994. Metode Perancangan Percobaan. CV. Armico. Bandung.
Hartmann, H.T., Kester DE. 1983. Plant Propagation -Principles and Practices. New Jersey (US). Prentice Hall International Inc. 238p.

Hastuti, E.D., E. Prihastuti dan R.B. Hastuti. 2000. Fisiologi Tumbuhan II. UNDIP. http://www.uripsumoharjo.com /read/article/95/button).

Diakses pada tanggal 03 April 2016

Kijkar, S. 1991. Producing Rooted Cuttings ofEucalyptus camaldulensis. ASEANCanada Forest Tree Seed Centre Project. Thailand

Krisnadi, A Dudi., 2015, Kelor Super Nutrisi, http://www. kelorina.com.Diakses pada tanggal 03April 2016 